(c) American Dairy Science Association, 2005.

\title{
Effect of Increasing Energy and Protein Intake on Mammary Development in Heifer Calves*
}

\author{
E. G. Brown, ${ }^{1}$ M. J. VandeHaar, ${ }^{1}$ K. M. Daniels, ${ }^{1}$ J. S. Liesman, ${ }^{1}$ L. T. Chapin, ${ }^{1}$ \\ J. W. Forrest, ${ }^{2}$ R. M. Akers, ${ }^{2}$ R. E. Pearson, ${ }^{2}$ and M. S. Weber Nielsen ${ }^{1}$ \\ ${ }_{1}^{1}$ Department of Animal Science, Michigan State University, East Lansing, 48824 \\ ${ }^{2}$ Department of Dairy Science, Virginia Polytechnic Institute and State University, Blacksburg, 24061
}

\begin{abstract}
The objective of this study was to determine if increased energy and protein intake from 2 to 14 wk of age would affect mammary development in heifer calves. At 2 wk of age, Holstein heifer calves were assigned to 1 of 4 treatments in a $2 \times 2$ factorial arrangement with 2 levels of protein and energy intake (moderate, M; high, $\mathrm{H}$ ) in period 1 (2 to $8 \mathrm{wk}$ of age) and 2 levels of protein and energy intake (low, L; high, H) in period 2 (8 to 14 wk of age), so that mean initial body weights were approximately equal for all 4 treatments (ML, MH, HL, and $\mathrm{HH}$ ). The $\mathrm{M}$ diet in period 1 consisted of a standard milk replacer $(21.3 \% \mathrm{CP}, 21.3 \%$ fat) fed at $1.1 \%$ of $\mathrm{BW}$ on a DM basis and a $16.5 \% \mathrm{CP}$ grain mix fed at restricted intake to promote $400 \mathrm{~g}$ of daily gain, whereas the L diet in period 2 consisted only of the grain mix. The $\mathrm{H}$ diet in period 1 consisted of a high-protein milk replacer $(30.3 \% \mathrm{CP}, 15.9 \%$ fat) fed at $2.0 \%$ of body weight on a $\mathrm{DM}$ basis and a $21.3 \% \mathrm{CP}$ grain mix available ad libitum. In period 2, the $\mathrm{H}$ diet consisted of just the $21.3 \%$ grain mix. Calves were gradually weaned from milk replacer by $7 \mathrm{wk}$ and slaughtered at $8(\mathrm{n}=11)$ or $14 \mathrm{wk}$ of age $(\mathrm{n}=41)$. Parenchyma from the distal region, midgland, and proximal region relative to the teat from one half of the udder was collected, fixed, and embedded in paraffin. The other half of the gland was used to determine parenchymal mass, protein, fat, DNA, RNA, and extraparenchymal mass. Total parenchymal tissue, parenchymal DNA, parenchymal RNA, and concentrations of DNA and RNA were higher for calves on the $\mathrm{H}$ diet during period 1 , but were not affected by diet during period 2 . Parenchymal fat percentage was increased by the $\mathrm{H}$ diet during period 2. The $\mathrm{H}$ diet increased extraparenchymal fat during both periods. The area of parenchyma occupied by epithelium was not affected by treatment, but

Received May 26, 2004.

Accepted October 6, 2004.

Corresponding author: M. S. Weber Nielsen; e-mail: msw@ msu.edu.

* Supported by the Michigan Corn Growers Association and the Michigan Corn Marketing Program.
\end{abstract}

at the end of period 2, the percentage of proliferating epithelial cells as indicated by Ki67, an marker of cell proliferation, expression was greater for calves on the $\mathrm{M}$ diet in period 1 compared with calves on the $\mathrm{H}$ diet in period 1. Diets did not influence parenchymal protein percentage or the ratio of RNA to DNA. Higher energy and protein intake from 2 to 8 wk of age increased parenchymal mass and parenchymal DNA and RNA in mammary glands of heifer calves without increasing deposition of parenchymal fat. Diet also influenced histological development of mammary parenchyma and subsequent proliferation of ductal epithelial cells. Implications of these effects for future milk production potential are unknown.

(Key words: calf, heifer, mammary development, nutrition)

Abbreviation key: D = distal, ER = estrogen receptor, $\mathbf{H}=$ high protein and energy intake, $\mathbf{M}=$ moderate protein and energy intake, $\mathbf{M I D}=$ mid-gland, $\mathbf{L}=$ low protein and energy intake, $\mathbf{P}=$ proximal, $\mathbf{S U B}=$ subtending ducts, $\mathbf{T D U}=$ terminal ductular units.

\section{INTRODUCTION}

Little is known about body growth rates during the period between birth and approximately 4 mo of age that encourage maximal mammary development and future milk production potential. Before approximately 9 mo of age, a critical period of heifer mammary growth exists during which mammary growth is allometric (Sinha and Tucker, 1969), and can be negatively affected by high energy intake (Sejrsen and Purup, 1997). However, in calves before weaning, 2 studies have reported that increased intake of whole milk was related to higher future milk production. For example, heifer calves consuming whole milk for BW gains of $1.1 \mathrm{~kg} / \mathrm{d}$ tended to produce more milk as cows than did heifers fed a restricted amount of whole milk before weaning (Foldager and Krohn, 1994). Bar-Peled et al. (1997) showed that calves suckling cows twice daily tended to produce more milk in their first lactations compared with similar heifers fed a defined amount of milk replacer, although it must 
be noted that the importance of the quantity of whole milk consumed relative to differences in diet composition and feeding method in this effect is unknown. Further evidence of the potential to increase the growth rates of young calves without negatively impacting mammary growth was provided by Sejrsen et al. (1998). This group demonstrated that heifer calves fed increased amounts of whole milk for a high rate of gain from birth until 6 wk of age had amounts of mammary parenchyma mass similar to those of heifers fed for moderate rates of gain when slaughtered at $12 \mathrm{wk}$ of age.

Only 1 study has been reported that addresses the potential for dietary manipulation of mammary development after weaning in calves younger than 3 mo of age. Using calves fed for 2 rates of gain after weaning, Petitclerc et al. (1999) showed that ad libitum feeding increased extraparenchymal tissue volume but reduced the amount of parenchymal tissue when data were adjusted for differences in BW at slaughter, indicating the potential for nutritional impairment of mammary development after the time of weaning around 2 mo of age.

The objective of this experiment was to determine if increasing energy and protein intake using commercial milk replacers and calf starters would affect mammary growth and development in heifer calves younger than 4 mo of age. Results of treatment effects on body growth rate and carcass composition are reported in a companion article (Brown et al., 2005).

\section{MATERIALS AND METHODS}

\section{Management of Calves}

All procedures were approved by the Animal Use and Care Committee of Michigan State University. Female Holstein calves ( $44.1 \pm 0.9 \mathrm{~kg} \mathrm{BW})$ were blocked by date of purchase, as described earlier by Brown et al. (2005). Following the 1-wk adaptation period, calves were randomly assigned to 1 of 4 treatments in a $2 \times 2$ factorial arrangement so that mean BW was not different among treatments. Withers height was not different among treatments at the start of the experiment.

In period 1, the moderate (M) diet consisted of milk replacer (Calvita Supreme, Milk Specialties Co., Dundee, IL; $21.3 \% \mathrm{CP}, 21.3 \%$ fat, $\sim 4.7 \mathrm{kcal}$ of $\mathrm{ME} / \mathrm{g}$ of DM guaranteed analysis) fed on a DM basis at $1.1 \%$ of BW (reconstituted to $11.8 \% \mathrm{DM}$ ), and starter grain (20.5\% CP guaranteed analysis; Gold Flake Calf Starter, Nutrena Feeds-Cargill, Inc., Minneapolis, MN) fed at restricted intake to achieve $0.40 \mathrm{~kg}$ of average daily gain from 2 to 8 wk of age. The high $(\mathbf{H})$ diet consisted of a high-protein milk replacer (Excelerate, Milk Specialties Co.; $30.3 \% \mathrm{CP}, 15.9 \%$ fat, approximately $4.4 \mathrm{kcal}$ of ME/ $\mathrm{g}$ of DM guaranteed analysis) fed on a DM basis at $2.0 \%$ of $\mathrm{BW}$ (reconstituted to $14.1 \% \mathrm{DM}$ ) and high-protein starter grain (25.0\% CP guaranteed analysis; Herd Builder Calf Starter, Nutrena Feeds-Cargill, Inc.) fed ad libitum. Calves were gradually weaned from milk replacer by 7 wk of age.

From 8 to 14 wk of age, calves on the low $(\mathbf{L})$ diet were fed grain at restricted intake to achieve $0.4 \mathrm{~kg}$ of average daily gain, whereas calves on the $\mathrm{H}$ diet were fed highprotein grain for ad libitum intake. From 8 to 9 wk of age, calves were fed only the respective calf starters, but beginning at 9 wk of age rolled corn was added to both diets. The new diets contained $70 \%$ of the respective calf starters and 30\% rolled corn. According to laboratory analyses, nutrient values for the new diets were $16.5 \%$ $\mathrm{CP}$ and $3.8 \%$ crude fat for the $\mathrm{L}$ diet, and $21.3 \% \mathrm{CP}$ and $3.7 \%$ crude fat for the $\mathrm{H}$ diet. Calves had fresh water available at all times.

\section{Tissue Collection}

One subset of calves ( 1 or 2 calves from each block; $\mathrm{n}=5$ calves on $\mathrm{M}$ diet; $\mathrm{n}=6$ calves on $\mathrm{H}$ diet) was randomly selected and slaughtered at 8 wk of age to assess mammary development at the end of period 1 . The remaining 41 calves were slaughtered at $14 \mathrm{wk}$ of age.

Calves were weighed on the afternoon of the day before slaughter. Calves were then fed and allowed $1 \mathrm{~h}$ to eat and drink water before being shipped to the Michigan State University Meats Laboratory at $1630 \mathrm{~h}$. Calves were slaughtered approximately 14 to $16 \mathrm{~h}$ after last feeding using captive bolt stunning followed by exsanguination. Within 15 min of slaughter, the mammary glands were collected. Mammary glands were bisected into right and left hemiglands and weighed. The left half was frozen flat in liquid nitrogen and stored at $-20^{\circ} \mathrm{C}$ for later analysis. Using the right half, samples of parenchymal tissue from the distal (D), midgland (MID), or proximal (P) region relative to the teat were excised from each calf, fixed for $24 \mathrm{~h}$ in buffered formalin, and then transferred to $70 \%$ ethanol for later analysis.

The reproductive tracts were examined to confirm that animals were not freemartins and had not reached puberty. One heifer was a freemartin and her data were eliminated from the results.

\section{Mammary Tissue Analysis}

The frozen left half of the udder was cut transversely using a band saw into slices 5 to $10 \mathrm{~mm}$ thick. Slices from both the anterior and posterior ends that did not contain parenchymal tissue were discarded. Skin, teats, and supramammary lymph nodes were removed. Extraparenchymal fat located outside the border of the parenchyma was weighed. The remaining parenchymal tissue 
was weighed and ground into a fine powder using liquid nitrogen in a Waring Blender (Waring Products Division, New Hartford, CT). The powder was mixed and subsampled for subsequent analysis of RNA and DNA (Tucker, 1964), DM, protein, and fat. Dry matter was determined by the difference from wet weight after the sample was placed in a $105^{\circ} \mathrm{C}$ oven for $24 \mathrm{~h}$. Ash was determined after $5 \mathrm{~h}$ of oxidation in a muffle furnace at $500^{\circ} \mathrm{C}$. Crude protein was analyzed according to Hach et al. (1987). Fat was determined by Soxhlet ether extraction (AOAC, 1990).

\section{Embedding of Tissue in Paraffin and Preparation of Slides}

Multiple pieces of parenchymal tissue from the D, MID, and $\mathrm{P}$ regions relative to the teat from one half of the udder were excised and fixed. Replicate tissue samples were embedded in paraffin. One replicate of paraffin-embedded tissue was used to prepare $5-\mu \mathrm{m}$-thick sections, and 4 or 5 serial tissue sections from each sample were placed on a microscope slide.

\section{General Staining Procedures}

Hydration of tissue sections began with a deparaffinization step that involved washing slides twice in xylene at $5 \mathrm{~min}$ per wash. Slides were then transferred through a series of ethanol washes at 2 min per wash (100, 95, and $70 \%$ ethanol). The final step in hydration was a 5min wash in distilled water. One slide representing each sample was placed in a hematoxylin and eosin solution (Sigma Chemical Co., St. Louis, MO) for $10 \mathrm{~min}$. Following completion of all staining procedures, tissue sections were again dehydrated, adhesive mounting medium (Permount, Fisher Chemicals, Fairlawn, NJ) was applied, cover slips were added to the slides and slides were allowed to dry overnight.

\section{Immunocytochemical Staining Procedures}

Identical staining procedures were used for the visualization of estrogen receptor (ER) and Ki67, a marker of cell proliferation. The only variation in procedure involved using different antibodies to identify each protein of interest. In contrast to the general staining procedures, which required that an entire slide receive the stain, multiple proteins were identified on the same microscope slide. The ER and Ki67 staining was performed on serial sections on 1 slide from each sample. Procedures were as described in recent reports (Capuco et al., 2002; Berry et al., 2003).

\section{Determination of Mammary Parenchymal Tissue Composition}

Hematoxylin and eosin-stained sections were examined at 40× magnification (Olympus BH-2, Opelco, Dulles, VA). Using a glass grid that was fitted onto the eyepiece of the microscope, areas of parenchymal tissue containing epithelium were randomly selected in 2 or more sections from each zone and were focused at $400 \times$ magnification. A series of images (6 per zone) were captured with a top-mount digital microscope camera (Olympus DP10, Opelco) and transferred to a computer for analysis. Saved images were examined using L-View Pro image analysis software (MMedia Research Corp., Hallandale, FL) by superimposing a $9 \times 8$ grid over the image. Each of the 72 intersection points was classified to determine if it was in contact with epithelium, lumen, or stroma within the parenchymal tissue region. Tissue proportions were determined by dividing the number of tissue specific intersection points by the total number of points counted.

\section{Developmental Categorization}

The previously described procedure for evaluating tissue composition only examined areas of tissue within lobular areas of apparent parenchymal tissue. Thus, this analysis focused on the relative development of parenchymal tissue compartments rather than overall mammary tissue development (i.e., intralobular areas of adipose and connective tissue were not included). Consequently, to characterize overall tissue development, 3 digital images were obtained from each zone using $40 \times$ magnification to represent a series of 3 developmental grades (i.e., $1=$ least developed to $3=$ most developed, based on the amount of parenchymal tissue present within the entire field). Stained tissue sections were subsequently viewed at $40 \times$ magnification and directly compared with control images simultaneously opened with L-View Pro software. Each sample was assigned a score to allow a semiquantitative evaluation of overall mammary tissue development. Three images per zone were evaluated and averaged for each animal.

\section{Determination of Percentage of ER- and Ki67-positive Epithelial Cells}

Slides containing tissue sections stained with primary antibody for ER and Ki67 were first examined under the microscope with the $4 \times$ objective. Examination under these low-power conditions allowed for epithelial structures to be distinguished as either subtending ducts (SUB) or terminal ductular units (TDU) as described by Capuco et al. (2002) and illustrated in Figure 1. However, abundance of staining was not evident. Subsequently, 


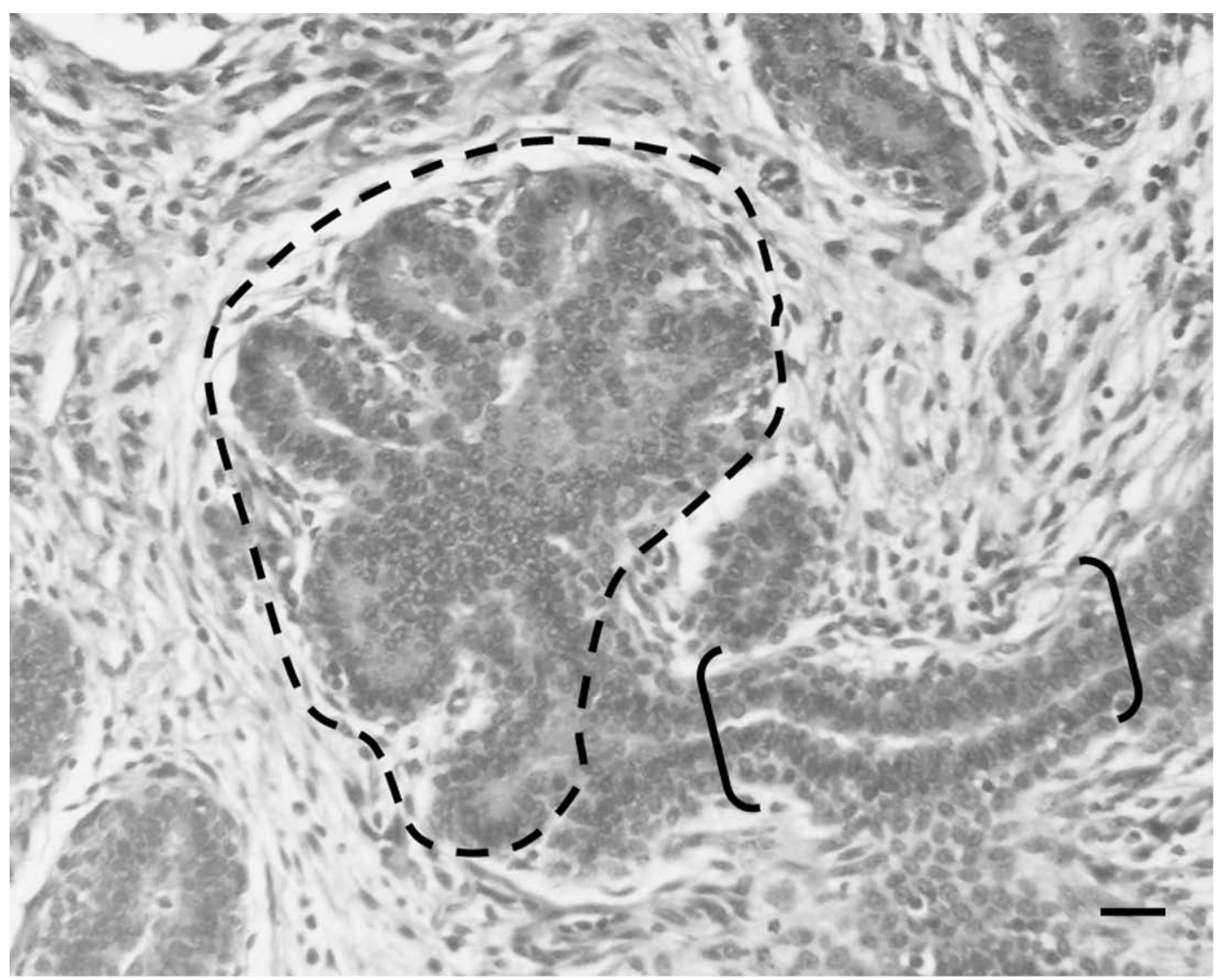

Figure 1. Hematoxylin and eosin-stained parenchymal mammary tissue from a prepubertal Holstein heifer. This image illustrates the structure of a developing ductal unit. A terminal ductal unit (TDU) is indicated by a dashed line and the associated subtending duct (SUB) is indicated by brackets. The bar indicates $50 \mu \mathrm{m}$.

3 areas of parenchymal tissue containing SUB and 3 containing TDU structures were randomly selected from ER- and Ki67-stained sections from each zone, refocused at higher magnification (40× objective), and photographed. These digital images were captured and stored on a computer for subsequent analysis.

For analysis, these images were opened with ImagePro Plus software (Media Cybernetics, Silver Spring, $\mathrm{MD})$ at $50 \%$ zoom, and a spatial calibration was made that allowed for the number of epithelial cells to be counted by outlining the epithelial structures using the computer mouse and cursor. The total numbers of ERand Ki67-positive cells within outlined areas were counted and divided by the total number of epithelial cells to calculate the proportion of either ER- or Ki67positive cells specifically within SUB or TDU structural elements. Approximately 1200 cells were counted for each variable within each image.

\section{Statistical Analyses}

Mammary gland variables for calves slaughtered at the end of period 1 were analyzed as a one-factor ANOVA with $\mathrm{M}$ and $\mathrm{H}$ diets as the treatments and date of purchase as the blocks. For the calves slaughtered at the end of period 2, all mammary variables except the histology variables were analyzed as a $2 \times 2$ factorial, with diets fed in period 1 ( 2 to $8 \mathrm{wk}$ of age) $\times$ the diets fed in period 2 (8 to $14 \mathrm{wk}$ of age). The data were analyzed using the GLM procedure of SAS 8.2 (SAS Inst., Inc., Cary, NC), with date of purchase as the block. Least squares means and standard errors of the mean are reported. Significance was declared at $P<0.05$, and trends at $P<0.10$.

Data for tissue histological evaluation (\% epithelium, $\%$ lumen, and \% stroma) were also analyzed using the GLM procedure of SAS. However, ER and Ki67 labeling responses within SUB and TDU structures within the mammary gland were evaluated to determine differences between these 2 structures. Comparisons between parenchymal zones (P, MID, or D) were analyzed as the linear contrasts of $\mathrm{D}$ vs. $\mathrm{MID}+\mathrm{P}$ and $\mathrm{D}$ vs. $\mathrm{P}$, and are reported as the estimate of the contrast. Because contrasts were nonorthogonal, comparisons were completed using Bonferroni tests of significance. 
Table 1. Least squares means for weight and composition of mammary glands of calves fed either the moderate $(\mathrm{M})$ or high $(\mathrm{H})$ diet and slaughtered at the end of period 1 (2 to 8 wk of age).

\begin{tabular}{lllll}
\hline Item & $\begin{array}{l}\text { Moderate } \\
(\mathrm{n}=5)\end{array}$ & $\begin{array}{l}\text { High } \\
(\mathrm{n}=6)\end{array}$ & SEM & $P>\mathrm{F}$ \\
\hline Total gland, g & 106 & 185 & 16 & 0.01 \\
Total gland, g/100 kg of BW & 181 & 255 & 22 & 0.05 \\
Parenchyma, g & 1.2 & 4.5 & 0.9 & 0.03 \\
Parenchyma, g/100 kg of BW & 1.9 & 6.2 & 1.1 & 0.03 \\
Extra-parenchymal fat, g & 10.7 & 36.0 & 4.4 & 0.005 \\
Extra-parenchymal fat, g/100 of kg BW & 18.1 & 49.5 & 6.1 & 0.009 \\
\hline
\end{tabular}

\section{RESULTS}

\section{Mammary Development}

Calves fed the $\mathrm{H}$ diet during period 1 (2 to $8 \mathrm{wk}$ of age) had 3 times the amount of parenchyma (per $100 \mathrm{~kg}$ $\mathrm{BW})$ at 8 wk of age compared with calves fed the $\mathrm{M}$ diet $(P=0.03$; Table 1). Also, calves fed the $\mathrm{H}$ diet compared with those fed the M diet from 2 to 8 wk of age had $50 \%$ more parenchyma (per $\mathrm{kg}$ of $\mathrm{BW}$ ) at $14 \mathrm{wk}$, regardless of which diet was consumed from 8 to 14 wk of age $(P=$ 0.02; Table 2). Diet during period 2 did not influence mass of mammary parenchyma per $100 \mathrm{~kg}$ of BW $(P=$ 0.76 ). Feeding the $\mathrm{H}$ diet during either period 1 or 2 increased the mass of mammary extraparenchymal fat per $100 \mathrm{~kg}$ of BW $(P<0.03$; Tables 1 and 2$)$.

Diet during period 1 did not alter the percentage of fat within mammary parenchymal tissue at $14 \mathrm{wk}(P=$ $0.24)$, but the $\mathrm{H}$ diet during period 2 increased parenchymal fat on a percentage basis $(P=0.03)$. Protein percentage within the mammary parenchymal tissue was unaffected by diet in either period.

Mammary parenchymal DNA and RNA per $100 \mathrm{~kg}$ of $\mathrm{BW}$ at 14 wk were higher for calves fed the $\mathrm{H}$ diet (HL and $\mathrm{HH}$ ) compared with the $\mathrm{M} \operatorname{diet}(\mathrm{ML}$ and $\mathrm{MH})$ during period 1 ( $P=0.004$ and $P=0.009$, respectively; Table
3). The $\mathrm{H}$ diet during period 1 increased concentrations of DNA and RNA in parenchymal tissue $(P=0.002$ and $P=0.06$, respectively). Diet during period 2 did not affect the amounts or concentrations of mammary parenchymal DNA or RNA. Diet did not affect the RNA:DNA ratio during either period 1 or 2 .

\section{Tissue Composition}

Feeding level did not significantly affect the percentage of epithelial area within mammary parenchyma. However, the interaction between periods was significant (Table $4, P=0.02$ ). The percentage of lumen was $3.5 \%$ greater $(P=0.01)$ for calves on the $\mathrm{H}$ diet in period 1 ( $\mathrm{HH}$ and $\mathrm{HL}$ ) vs. calves on the $\mathrm{M} \operatorname{diet}(\mathrm{MH}$ and $\mathrm{ML}$ ). Opposite treatment effects were demonstrated with respect to percentage of stroma, which was $4.0 \%$ lower $(P=0.02)$ for calves on the $\mathrm{H}$ diet in period 1 ( $\mathrm{HH}$ and HL) vs. calves on the M diet (MH and ML). Percentages of epithelium in mammary parenchymal tissue did not differ significantly between zones of the gland and averaged $19.6 \%$. There was $3.9 \%$ less $(P=0.01)$ lumenal area and $5.3 \%$ more $(P=0.004)$ stromal area in zone $\mathrm{D}$ vs. $\mathrm{MID}+\mathrm{P}$ (Table 5), and values were similar for D vs. P.

Table 2. Least squares means for weight and composition of mammary glands of calves fed either the moderate $(\mathrm{M})$ or high $(\mathrm{H})$ diet during period 1 (2 to 8 wk of age) and low (L) or $\mathrm{H}$ diet during period 2 ( 8 to $14 \mathrm{wk}$ of age) and slaughtered at the end of period 2.

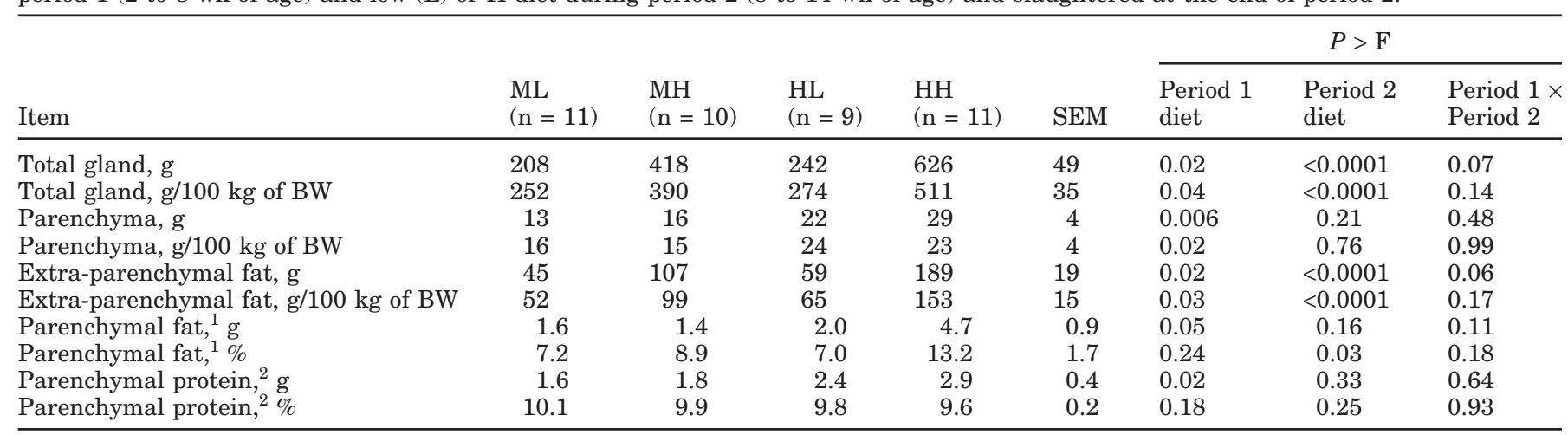

${ }^{1}$ Data represent results for 7 heifers on ML, 8 on MH, 7 on HL, and 9 on HH treatments.

${ }^{2}$ Data represent results for 7 heifers on $\mathrm{ML}, 8$ on $\mathrm{MH}, 7$ on HL, and 10 on $\mathrm{HH}$ treatments. 
Table 3. Least squares means for nucleic acid content of mammary glands of calves fed either the moderate (M) or high $(\mathrm{H})$ diet during period 1 (2 to $8 \mathrm{wk}$ of age) and low (L) or $\mathrm{H}$ diet during period 2 (8 to 14 wk of age) and slaughtered at the end of period 2.

\begin{tabular}{|c|c|c|c|c|c|c|c|c|}
\hline \multirow[b]{2}{*}{ Item } & \multirow[b]{2}{*}{$\begin{array}{l}\mathrm{ML} \\
(\mathrm{n}=11)\end{array}$} & \multirow[b]{2}{*}{$\begin{array}{l}\text { MH } \\
(\mathrm{n}=10)\end{array}$} & \multirow[b]{2}{*}{$\begin{array}{l}\mathrm{HL} \\
(\mathrm{n}=9)\end{array}$} & \multirow[b]{2}{*}{$\begin{array}{l}\mathrm{HH} \\
(\mathrm{n}=11)\end{array}$} & \multirow[b]{2}{*}{ SEM } & \multicolumn{3}{|c|}{$P>\mathrm{F}$} \\
\hline & & & & & & $\begin{array}{l}\text { Period } 1 \\
\text { diet }\end{array}$ & $\begin{array}{l}\text { Period } 2 \\
\text { diet }\end{array}$ & $\begin{array}{l}\text { Period } 1 \times \\
\text { Period } 2\end{array}$ \\
\hline Parenchymal DNA, mg & 39 & 45 & 78 & 108 & 16 & 0.002 & 0.24 & 0.43 \\
\hline DNA, $m g / 100 \mathrm{~kg}$ of BW & 44 & 42 & 85 & 86 & 14 & 0.004 & 0.94 & 0.93 \\
\hline Concentration DNA, mg/g & 2.59 & 2.61 & 3.19 & 3.49 & 0.23 & 0.002 & 0.45 & 0.51 \\
\hline Parenchymal RNA, mg & 54 & 67 & 93 & 136 & 18 & 0.003 & 0.10 & 0.39 \\
\hline $\mathrm{RNA}, \mathrm{mg} / 100 \mathrm{~kg}$ of $\mathrm{BW}$ & 63 & 63 & 103 & 108 & 16 & 0.009 & 0.85 & 0.86 \\
\hline Concentration RNA, mg/g & 4.15 & 4.12 & 4.24 & 4.77 & 0.19 & 0.06 & 0.18 & 0.14 \\
\hline RNA:DNA & 1.67 & 1.62 & 1.45 & 1.43 & 0.14 & 0.14 & 0.78 & 0.91 \\
\hline
\end{tabular}

\section{Developmental Categorization}

Mean developmental categorization score averaged 2.1 across all treatments, but ML calves had the lowest overall developmental score (1.6) (Figure 2). Calves on the $\mathrm{H}$ diet in period 2 had a higher $(P=0.001)$ developmental score than calves on the $\mathrm{L}$ diet in period 2 . For developmental score related to period 1 , the contrast of $(\mathrm{HH}+\mathrm{HL})$ vs. $(\mathrm{MH}+\mathrm{ML})$ was non significant. However, during period 2, the contrast of $(\mathrm{HH}+\mathrm{MH})$ vs. $(\mathrm{HL}+$ $\mathrm{ML})$ was significant $(P=0.0006)$ for developmental score. Differences between zones of the mammary gland were also seen with regard to level of development. Tissue collected from zone D scored 0.40 and 0.31 units lower ( $P=0.007$ and $P=0.07$, respectively) than tissue from zones MID and $\mathrm{P}$ together or zone $\mathrm{P}$ alone (data not shown). The interaction of zone and treatment on developmental score was not significant $(P=0.17)$.

\section{Estrogen Receptor and Ki67}

Feeding level did not significantly affect the percentage of ER-positive epithelial cells in SUB or TDU. How- ever, there was an interaction of diet and period for percentage of ER (SUB) $(P=0.04)$. The Ki67 expression was affected by feeding level (Table 4). In SUB, the percentage of Ki67-positive epithelial cells was lower in calves on the $\mathrm{H}$ diet in period 1 vs. calves on the $\mathrm{M}$ diet (3.7 vs. $5.1 \%, P=0.05$ ). Similar dietary effects were noted in TDU, with calves on the $\mathrm{H}$ diet in period 1 having fewer Ki67-positive cells than calves on the $\mathrm{M}$ $\operatorname{diet}(4.2$ vs. $6.3 \%, P=0.01)$.

Neither ER nor Ki67 expression was significantly affected by mammary zone (data not shown). The mean percentages of ER-positive epithelial cells in zones D, MID, and $\mathrm{P}$ were $49.5 \%, 50.5$, and 47.5 , respectively. The mean percentages of Ki67-positive epithelial cells in zones $\mathrm{D}, \mathrm{MID}$, and $\mathrm{P}$ were 5.4, 3.9, and 5.0\%. However, significant differences existed in epithelial structure with respect to ER expression. Specifically, percent ERpositive epithelial cells averaged $47 \%$ in SUB compared with $52 \%$ in TDU, respectively $(P=0.0001)$.

\section{DISCUSSION}

Our study demonstrates that increased energy and protein intake associated with accelerated calf growth

Table 4. Least squares means for mammary parenchymal tissue composition, and percentage of epithelial cells positive for estrogen receptor (ER) and Ki67 labeling. Tissue was harvested from calves fed either the moderate $(\mathrm{M})$ or high $(\mathrm{H})$ diet during period 1 (2 to 8 wk of age) and low (L) or $\mathrm{H}$ diet during period 2 (8 to $14 \mathrm{wk}$ of age)and slaughtered at the end of period 2 .

\begin{tabular}{|c|c|c|c|c|c|c|c|c|}
\hline \multirow[b]{2}{*}{ Item $(\%)$} & \multirow[b]{2}{*}{ ML } & \multirow[b]{2}{*}{$\mathrm{MH}$} & \multirow[b]{2}{*}{ HL } & \multirow[b]{2}{*}{$\mathrm{HH}$} & \multirow[b]{2}{*}{$\mathrm{SEM}^{1}$} & \multicolumn{3}{|c|}{$P>\mathrm{F}$} \\
\hline & & & & & & $\begin{array}{l}\text { Period } 1 \\
\text { diet }\end{array}$ & $\begin{array}{l}\text { Period } 2 \\
\text { diet }\end{array}$ & $\begin{array}{l}\text { Period } 1 \times \\
\text { Period } 2\end{array}$ \\
\hline Epithelium & 17.9 & 20.9 & 20.5 & 19.2 & 1.0 & 0.64 & 0.35 & 0.02 \\
\hline Lumen & 5.7 & 7.0 & 9.7 & 10.1 & 1.5 & 0.01 & 0.52 & 0.74 \\
\hline Stroma & 76.4 & 72.1 & 69.8 & 70.7 & 1.8 & 0.02 & 0.31 & 0.13 \\
\hline $\mathrm{ER}^{+}\left(\mathrm{SUB}^{2}\right)$ & 49.8 & 43.1 & 46.7 & 48.9 & 2.5 & 0.54 & 0.30 & 0.04 \\
\hline $\mathrm{ER}^{+}\left(\mathrm{TDU}^{3}\right)$ & 51.7 & 50.5 & 52.1 & 53.0 & 2.7 & 0.53 & 0.96 & 0.66 \\
\hline $\mathrm{Ki}^{2} 7^{+}\left(\mathrm{SUB}^{2}\right)$ & 6.1 & 4.0 & 3.6 & 3.7 & 0.8 & 0.05 & 0.18 & 0.11 \\
\hline $\mathrm{Ki}^{+} 7^{+}\left(\mathrm{TDU}^{3}\right)$ & 6.9 & 5.6 & 3.9 & 4.5 & 0.9 & 0.01 & 0.68 & 0.24 \\
\hline
\end{tabular}

${ }^{1}$ Largest SEM for each variable.

${ }^{2} \mathrm{SUB}=$ Subtending duct.

${ }^{3} \mathrm{TDU}=$ Terminal ductular unit. 
Table 5. Least squares means for mammary parenchymal tissue composition for tissue collected from the distal one third of parenchyma relative to the teat (D), mid-gland (MID), or from the proximal one third $(\mathrm{P})$.

\begin{tabular}{lllllll}
\hline & & Zone & & & \multicolumn{2}{c}{ Contrast, $P$-value (SEM) } \\
\cline { 2 - 3 } \cline { 6 - 7 } Item $(\%)$ & $\mathrm{D}$ & MID & $\mathrm{P}$ & & $\mathrm{D}$ vs. MID+P & D vs. P \\
\hline Epithelium & 18.7 & 19.8 & 20.4 & & $-1.4,0.17$ & $-1.7,0.15$ \\
& $(0.8)$ & $(0.8)$ & $(0.9)$ & & $(1.0)$ & $(1.2)$ \\
Lumen & 5.5 & 9.2 & 9.7 & & $-3.9,0.01$ & $-4.1,0.02$ \\
& $(1.2)$ & $(1.2)$ & $(1.3)$ & & $(1.5)$ & $(1.7)$ \\
Stroma & 75.8 & 71.0 & 70.0 & & $+5.3,0.004$ & $+5.8,0.007$ \\
& $(1.4)$ & $(1.5)$ & $(1.6)$ & & $(1.8)$ & $(2.1)$ \\
\hline
\end{tabular}

programs increases growth of mammary parenchyma in calves from 2 to $8 \mathrm{wk}$ of age. The extent of development of mammary parenchyma in heifers is important, because the number of mammary cells is a major factor limiting milk production (Tucker, 1981). From about 4 mo of age until puberty, mammary development is negatively affected by rapid body growth rates. Little is known, however, about how growth rates during the period from birth to approximately 4 mo of age are related to mammary development and future milk production potential.

Calves fed the $\mathrm{H}$ diet in period 1 in our study had more mammary parenchymal tissue per $100 \mathrm{~kg}$ of BW compared with calves on the $\mathrm{M}$ diet in period 1 . In another study with a treatment period from $5 \mathrm{~d}$ to $6 \mathrm{wk}$ of age, Sejrsen et al. (1998) showed that calves on either a high or moderate feeding level had similar amounts of mammary parenchyma when slaughtered at similar ages. Similarly, heifer calves fed a high-energy diet for ad libitum intakes from $6 \mathrm{wk}$ to 4 mo of age had greater mammary volume $\left(1067 \mathrm{~cm}^{3}\right)$ than control heifers $(335$

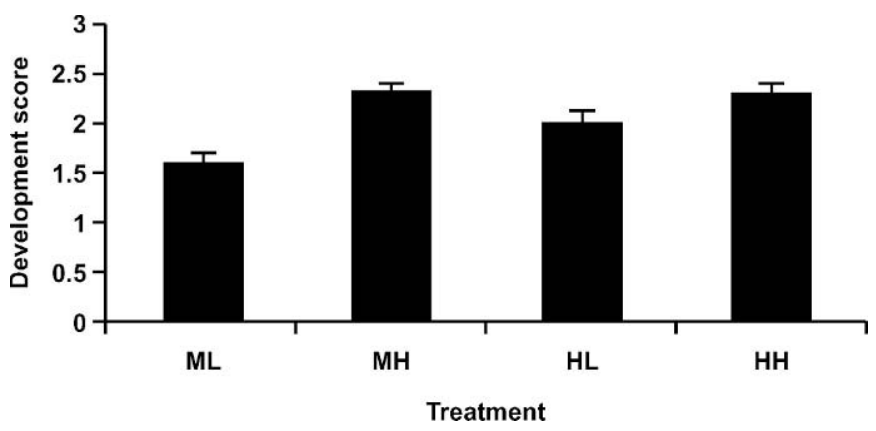

Figure 2. Mammary tissue development score. Data are presented as least squares means and SEM. Tissue was harvested from calves fed either the moderate $(\mathrm{M})$ or high $(\mathrm{H})$ diet during period 1 (2 to 8 wk of age) and low (L) or $\mathrm{H}$ diet during period 2 ( 8 to 14 wk of age) and slaughtered at the end of period 2 . For period 1 , the contrast of $\mathrm{HH}+\mathrm{HL}$ vs. $\mathrm{MH}+\mathrm{ML}$ was not significant; however, during period 2, the contrast of $\mathrm{HH}+\mathrm{MH}$ vs. $\mathrm{HL}+\mathrm{ML}$ was highly significant $(P$ $<0.001)$. $\mathrm{cm}^{3}$ ) (Petitclerc et al., 1999). Petitclerc et al. (1999) found an increase in parenchymal volume in heifers fed ad libitum, but there was $28 \%$ less parenchymal volume after adjusting for BW. However, heifers on their study did not start treatments until $6 \mathrm{wk}$ of age. The older, postweaning age at start of treatment may explain the difference in treatment effects compared with our study.

In period 2 , the calves on the $\mathrm{H}$ diet had a higher percentage of mammary parenchymal fat, but parenchymal growth was unaffected by diet, similar to the results of Petitclerc et al. (1999). In a study with older but still prepubertal heifers by Capuco et al. (1995), heifers on a corn silage diet gaining $1.0 \mathrm{~kg} / \mathrm{d}$ from $175 \mathrm{~kg}$ of BW until $333 \mathrm{~kg}$ of BW had a higher parenchymal fat percentage than did heifers growing at $0.78 \mathrm{~kg} / \mathrm{d}$ on a corn silage diet or heifers growing at either rate of gain on an alfalfa silage diet. Heifers growing at a high rate of gain on the corn silage diet also had a similar amount of mammary parenchymal tissue compared with heifers in the other 3 groups, but there was an increase in number of adipocytes and a decrease in epithelial cell number. Elongation of the primary ducts was not affected by dietary treatment, but there was decreased branching of the ducts in heifers on the high corn diet. As described by Akers (1990), epithelial cells of the growing ducts pursue stromal growth into the mammary fat pad of heifers, with the absence of epithelial cells adjacent to adipocytes suggesting that mammary adipose tissue might inhibit epithelial cell proliferation.

The $\mathrm{H}$ diet in period 1 also increased parenchymal DNA and RNA amount and DNA concentration, and tended to increase RNA concentration. The amount of DNA is an indicator of the number of secretory cell numbers and RNA is an indicator of metabolic activity (Tucker, 1969). The increase in DNA suggests that calves on the $\mathrm{H}$ diet in period 1 would produce more milk as cows. In a study by Bar-Peled et al. (1997), heifers with similar BW gains from birth to $6 \mathrm{wk}$ of age as calves on the $\mathrm{H}$ diet in our study tended to produce more milk as cows. Foldager and Krohn (1994) determined that heif- 
ers with higher weight gains $(1.1 \mathrm{~kg} / \mathrm{d})$ from birth to 8 wk of age tended to produce more milk as cows than did heifers fed for $0.58 \mathrm{~kg} / \mathrm{d}$ from birth through $6 \mathrm{wk}$ of age. However, in both of these studies, high growth rates were achieved by feeding whole milk. It is possible that other factors, such as hormones and growth factors found in cows' milk, but not in milk replacer, contributed substantially to the observed effects on milk production.

The lack of differences in percentage of epithelium within the parenchymal tissue suggests that none of the dietary treatments markedly affected the overall pattern of ductular tissue development. Regardless, heifers receiving the $\mathrm{H}$ diet during the first period had greater percentages of parenchymal lumen area compared with heifers on the $\mathrm{M}$ diet. These results may indicate that feeding a diet higher in protein and energy between 2 and 8 wk of age increased development of mammary parenchymal tissue structures, supporting the data regarding parenchymal mass (Table 2), DNA, and RNA concentration (Table 3). However, larger lumens do not necessarily indicate better mammary development in terms of future milk production potential. Larger ducts with increased lumenal diameters may represent the appearance of ducts that are developmentally more mature than is normal for the peripubertal stage of development. If these duct structures are less able to support the markedly increased rate of epithelial cell proliferation and the subsequent allometric growth occurring with the onset of estrous cycles and pregnancy, this would clearly be detrimental. It is logical to assume that this increased lumenal area would be accompanied by a decrease in stroma, which was the case (Table 4).

Because the procedure for determining tissue composition used intersection points in contact only with parenchyma, this means of data collection would not have detected differences between tissue sections in the amount of area occupied by ducts. Consequently, a semiquantitative analysis (developmental score) was designed. This assessment reflects the amount of parenchymal tissue present in entire mammary tissue sections, whereas our parenchymal tissue composition analysis evaluates the tissue composition specifically within parenchyma. Heifers fed the $\mathrm{H}$ diet during period $2 \mathrm{had}$ increased developmental scores (Figure 2), possibly reflecting the numerically higher average parenchymal weight for heifers on the $\mathrm{H}$ diet in period 2 .

Heifers fed the $\mathrm{M}$ diet during period 1 demonstrated increased epithelial cell proliferation (Ki67) in both SUB and TDU (Table 4) compared with heifers on the H diet, despite also having a lower developmental score. These data support our suggestion that heifers subjected to the $\mathrm{H}$ diet in period 1 have larger, more mature ducts (increased lumenal area) that subsequently exhibit a reduced rate of epithelial cell proliferation. That is, heif- ers with the highest proportions of proliferating epithelial cells (MH and ML) also possessed the least amount of lumenal space. It is possible that heifers fed for a high rate of gain early are primed for reductions in mammary growth after $14 \mathrm{wk}$ of age, as the reduced percentage of Ki67-labeled epithelial cells in these animals suggests.

Epithelial cell ER expression in SUB and TDU did not differ in response to feeding regimen (Table 4). Although it is has been apparent for some time that estrogen plays a crucial role in mammary development (Wallace, 1958), these results suggest that mammary growth differences resulting from dietary treatments are not due to direct interactions between estrogen and its receptor. This does not imply that estrogen had no effect on the mammary developmental variation observed in this study. For example, estrogen is required for the normal function of IGF-I, which is a potent mitogen for prepubertal mammary growth (Ruan et al., 1995). These results also do not imply that the ER was not responsible for mammary growth differences between feeding treatments. It has been postulated that various growth factors, such as IGF-I and epidermal growth factor, might directly stimulate the ER in the absence of its natural ligand (Woodward et al., 2000). Interestingly, calves on the $\mathrm{H}$ diet in period 1 exhibited higher plasma IGF-I (Brown et al., 2005) and greater parenchymal growth; however, higher plasma IGF-I concentrations in calves on the $\mathrm{H}$ diet in period 2 were not accompanied by greater parenchymal growth than that of calves on the L diet. Dietary control at the local tissue level is clearly complex, with multiple players, and our understanding is minimal particularly of the ruminant. In addition, the interaction of period 1 and period 2 on ER expression in SUB would seem to suggest that dietary effects on mammary tissue growth and morphogenesis are not constant across all stages of development even during the prepubertal period.

Surprisingly, there were no differences in epithelial cell proliferation between zones of the mammary gland. The expectation was that there would be a greater number of proliferating cells at the leading edge of parenchymal penetration into the fat pad (zone D). This suggests that epithelial growth was similar between more mature ductular structures and newer, or more immature, structures at 14 wk of age. Thus, development of side branching appears to be as crucial as TDU expansion in terms of ductular growth early in heifer mammary gland development. Direct support for this comes from the finding that SUB, which would be more prevalent in zones closer to the teat, had a proliferative capacity that was similar to TDU.

When ER and Ki67 expression were categorized by structure, TDU were found to have a significantly greater percentage of ER-positive epithelial cells than 
SUB (52.4 vs. $46.6 \%$ ). In the pubertal mouse model, disruption of certain extracellular proteins led to structurespecific inhibition of ductular growth. For example, blockage of $\beta 1$ integrin, an epithelial cell receptor for the extracellular matrix, reduced terminal end bud number, whereas the remaining gland architecture appeared normal (Klinowska et al., 1999). Our results regarding ER expression in TDU point to a possible structure-specific role for estrogen, or other ER binding proteins, in ductular morphogenesis of the prepubertal heifer mammary gland. The lack of difference between TDU and SUB in Ki67 expression was unexpected. It was anticipated that TDU would have greater cell proliferation numbers due to the fact that these structures comprise the majority of sites where active ductular expansion is occurring. Again, this may be a reflection of the relatively young age of these heifers. Capuco et al. (2002) showed that the percentage of bromodeoxyuridine-labeled epithelial cells increased progressively from the cisternal to the outer regions of the parenchyma in heifers at $3 \mathrm{mo}$ of age. At young ages, it may be that TDU throughout the parenchyma are uniformly active. On the other hand, relative differences in tissue composition in the $\mathrm{D}$ compared with the $\mathrm{P}$ zones (less lumenal space and more stromal tissue) do reflect the expected developmental pattern of progressively more mature tissue near the teat and cistern. This was also reflected in the significantly lower developmental score for D vs. MID+P (1.79 vs. 2.20).

\section{CONCLUSIONS}

Increasing energy and protein intake from 2 to $8 \mathrm{wk}$ of age increased mammary parenchymal mass, DNA and RNA of Holstein heifer calves. Increased energy and protein intake from 8 to $14 \mathrm{wk}$ of age did not increase mass of mammary parenchymal tissue or DNA concentration, but encouraged deposition of both intraparenchymal and extraparenchymal fat. We conclude that increasing protein and energy intake in Holstein heifer calves from 2 to $8 \mathrm{wk}$ of age can increase the rate of development of mammary parenchyma. Whether this increase would translate into more milk production later in life is not clear, given the subsequent reduction in rate of cell proliferation in the mammary parenchyma. We suggest that early rapid growth is at least not detrimental if intraparenchymal fat content of the mammary gland is not increased.

\section{ACKNOWLEDGMENTS}

We are grateful to Milk Specialties, Inc., for the generous donation of milk replacer, and to T. Scott, D. Grooms, and M. Van Amburgh for valuable input on the experiment.

\section{REFERENCES}

Akers, R. M. 1990. Lactation physiology: A ruminant perspective. Protoplasma 159:96-111.

AOAC. 1990. Official Methods of Analysis. Vol. 1. 15th ed. Assoc. Off. Anal. Chem., Int., Arlington, VA.

Bar-Peled, U., B. Robinzon, E. Maltz, H. Tagari, Y. Folman, I. Bruckental, H. Voet, H. Gacitua, and A. R. Lehrer. 1997. Increased weight gain and effects on production parameters of Holstein heifer calves that were allowed to suckle from birth to six weeks of age. J. Dairy Sci. 80:2523-2528.

Berry, S. D. K., P. M. Jobst, S. E. Ellis, R. D. Howard, A. V. Capuco, and R. M. Akers. 2003. Mammary epithelial proliferation and estrogen receptor $\alpha$ expression in prepubertal heifers: Effects of ovariectomy and growth hormone. J. Dairy Sci. 86:2098-2105.

Brown, E. G., M. J. VandeHaar, K. M. Daniels, J. S. Liesman, L. T. Chapin, D. H. Keisler, and M. S. Weber Nielsen. 2005. Effect of increasing energy and protein intake on body growth and carcass composition of heifer calves. J. Dairy Sci. 88:585-594.

Capuco, A. V., S. Ellis, D. L. Wood, R. M. Akers, and W. Garrett. 2002. Postnatal mammary ductal growth: Three-dimensional imaging of cell proliferation, effects of estrogen treatment and expression of steroid receptors in prepubertal calves. Tissue Cell 34:143-154.

Capuco, A. V., J. J. Smith, D. R. Waldo, and C. E. Rexroad, Jr. 1995. Influence of prepubertal dietary regimen on mammary growth of Holstein heifers. J. Dairy Sci. 78:2709-2725.

Foldager, J., and C. C. Krohn. 1994. Heifer calves reared on very high or normal levels of whole milk from birth to six to eight weeks of age and their subsequent milk production. Proc. Soc. Nutr. Physiol. 3:301. (Abstr.)

Hach, C. C., B. K. Bowden, A. B. Lopelove, and S. V. Brayton. 1987. More powerful peroxide Kjeldahl digestion method. J. AOAC 70:783-787.

Klinowska, T. C. M., J. V. Soriano, G. M. Edwards, J. M. Oliver, A. J. Valentijn, R. Montesano, and C. H. Streuli. 1999. Laminin and $\beta 1$ Integrins are crucial for normal mammary gland development in the mouse. Dev. Biol. 215:13-32.

Petitclerc, D., P. Dumoulin, H. Ringuet, J. Matte, and C. Girard. 1999. Plane of nutrition and folic acid supplementation between birth and four months of age on mammary development of dairy heifers. Can. J. Anim. Sci. 79:227-234.

Ruan, W., V. Catanese, R. Wieczorek, M. Feldman, and D. L. Kleinberg. 1995. Estradiol enhances the stimulatory effect of IGF-I on mammary development and growth hormone-induced IGF-I mRNA. Endocrinology 136:1296-1302.

Sejrsen, K., and S. Purup. 1997. Influence of prepubertal feeding level on milk yield potential of dairy heifers: A review. J. Anim. Sci. 75:828-835.

Sejrsen, K., S. Purup, H. Martinussen, and M. Vestergaard. 1998. Effect of feeding level on mammary gland growth in calves and prepubertal heifers. J. Dairy Sci. 81(Suppl. 1):377. (Abstr.)

Sinha, Y. N., and H. A. Tucker. 1969. Mammary development and pituitary prolactin level of heifers from birth through puberty and during the estrous cycle. J. Dairy Sci. 52:507-512.

Tucker, H. A. 1964. Influence of number of suckling young on nucleic acid content of lactating rat mammary gland. Proc. Soc. Exp. Biol. Med. 116:218-220.

Tucker, H. A. 1969. Factors affecting mammary gland cell numbers. J. Dairy Sci. 52:720-729.

Tucker, H. A. 1981. Physiological control of mammary growth, lactogenesis and lactation. J. Dairy Sci. 64:1403-1421.

Wallace, C. 1958. Observations on mammary development in calves and lambs. J. Agric. Sci. 43:413-421.

Woodward, T. L., J. Xie, J. L. Fendrick, and S. Z. Haslam. 2000. Proliferation of mouse mammary epithelial cells in vitro: Interactions among epidermal growth factor, insulin-like growth factor, ovarian hormones, and extracellular matrix proteins. Endocrinology 141:3578-3586. 